\title{
LUCYNA STANISZEWSKA
}

Adam Mickiewicz University, Poznań, Poland

Faculty of Law and Administration

https:// orcid.org/0000-0003-3457-0901

\section{The right to health for all and problems with the interference of administrative law in medical professions during the COVID-19 pandemic}

Abstract: The legislative changes concerning health protection issues presented in the article are temporary, however, it is not known how long the pandemic will last. Defrosting the economy is risky, but necessary for the proper functioning of the state. Too hasty "loosening" of the medical services sector may increase the incidence and, consequently, affect other spheres of life. Therefore, it is so important and a priority to maintain precautionary measures as long as possible, which justifies the actions taken by the state and interfering with the sphere of functioning of medical entities.

The article attempts to answer the question whether the right to health protection has been limited by COVID-19.

It should be noted that health services other than those related to epidemic control have been significantly reduced. Specialists who dealt with, among others aesthetic medicine or dentistry could be delegated to work on COVID-19. As a result, both medical entities providing these services and patients were restricted from using such services, and consequently were prevented from fully exercising their right to health protection.

Keywords: legal regulation of health protection, work orders for doctors, administrative fines, regulations during the COVID-19 pandemic 


\section{Introduction}

Firstly, the issue of patient's rights under Polish and international legislation. Secondly, the right to health in the state of epidemic. Thirdly, the use of health care services during the epidemic, and what is more, the comparison of these second generation rights, i.e. social rights, with the right to work and its choosing by health care workers in Poland. Legal regulations restricting workers' freedoms by way of administrative and legal regulations will be presented as well. Summarizing my paper I will provide some conclusions for the future, which can be used by the Polish legislator, but also in other countries threatened with epidemic states.

\section{Patient's rights under Polish and international legislation}

Patient rights is a term used to refer to patient rights and freedoms that are guaranteed by the state. In Poland, patient rights are defined not only by the Charter of Patients' Rights, but also by a number of other documents adopted by the government. It's time to find out what the patient has and what he can demand ${ }^{1}$. In Poland, the patient's rights are defined by the Constitution of the Republic of Poland of April 2, $1997^{2}$. It should be pointed out that the implementation of obligations in the field of protection health, as imposed on public authorities by the Constitution, with international obligations under the Universal Declaration of Human Rights and the International Covenant on Economic,

\footnotetext{
1 More about patient's rights in: D. Karkowska, Prawa pacjenta, Warszawa 2009,
} s. 23 in.

2 Journal of Law of 1997, No. 78, item 483. 
Social and Cultural Rights ${ }^{3}$. The necessity to fulfill international obligations of a state may positively influence the activities of public authorities in this regard. The functioning of the health care system is undoubtedly questionable, but extending the possibility of challenging the constitutional right to health care is not a way to solve these problems. For example, if the constitutional right to health protection, to the extent that constitutes a social law will be established as the basis for claims before common courts, it may only lead to burdening health care institutions with possible additional costs and will not replace legislative system activities.

The Act on Patient Rights and Patient's Rights Ombudsman, adopted by the Parliament on November 6, 2008, is also important. It distinguishes the patient's rights in detail, the implementation of which may be demanded in medical facilities throughout the country. The Act also allows for a request for help and intervention to the Patient Ombudsman.

One should take into account that under art. 68 clause 1 of the Polish Constitution, everyone has the right to health. Therefore, it is justified to emphasize that human health is one of the most important personal rights. It is the human right in the category of social rights. It is worth noting the heterogeneous standpoint of the Constitutional Tribunal, which in the judgment of 24 February 2004 qualified the right arising from art. 68 as "a typical social right in the narrow sense, that is, the right to certain material benefits from public authorities"4. However, the Constitutional Tribunal in another judgment of 23 March 1999 stated that from art. 68 clause 1 of the

3 International Covenant on Economic, Social and Cultural Rights of December 19, 1966 (Journal of Laws No.

of 1977 , No. 38 , item 169)

4 Judgment of the Constitutional Tribunal dated February 24, 2004, file ref. K 54/02 (OTK 2004, series A, No. 2, item 10). 
Constitution one should deduce "the individual's right to health and an objective order for public authorities to take such actions that are necessary for the proper protection and implementation of this

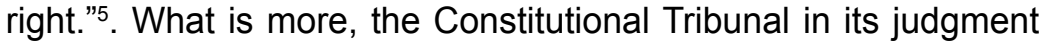
of 7 January 2004 stated that "the content of the right to health is not some abstract condition of health of individual entities, but it is the possibility of using a health care system functionally focused on combating and preventing diseases, injuries and disabilities" 6 .

Another problem that needs to be considered is whether subjective rights or a programmatic norm arise from article 68 of the Constitution ${ }^{7}$. Social rights constitute programmatic norms but it is possible to read the programmatic norms in such a way that a certain minimum of rights is coded therein, which corresponds to the minimum of obligations of public authorities. In this case, the role of the state is to be active in the pursuit of individual rights ${ }^{8}$.

Constitutional fundamental rights are subjective rights and as such may be the basis of individual claims. Constitutional social rights are program standards and, in principle, cannot be the basis for such claims. The right to health protection is, to a certain extent, a fundamental right, primarily due to its direct connection with human dignity, and in this respect, from it subjective rights that may be the basis for claims of individuals. It follows from

5 Judgment of the Constitutional Tribunal dated March 23, 1999, file ref. K 2/98 (OTK ZU 1999, No. 3, item 38).

6 Judgment of the Constitutional Tribunal dated January 7, 2004, file ref. K 14/03 (OTK ZU 2004, series

A, no.1, item 1).

7 J. Boć (red.), Konstytucje Rzeczypospolitej oraz komentarz do konstytucji RP z 1997 roku, Wrocław 1998, s. 78.

8 M. Piechota, Konstytucyjne prawo do ochrony zdrowia jako prawo socjalne i prawo podstawowe, ROCZNIKI ADMINISTRACJI I PRAWA. TEORIA I PRAKTYKA. ROK XII, Sosnowiec 2012, s. 95. 
dignity because the right to use the highest attainable level of health. However, the right to health protection was shaped by the constitutional legislator as a social right and in this respect, as a rule, does not constitute the basis for citizens' claims ${ }^{9}$.

The first case of coronavirus infection in Poland was confirmed on 4 March 2020. On 8 March 2020, the Act of 2 March 2020 on special measures to prevent, counter and combat COVID-19, other infectious diseases and the related crisis emergencies entered into force ${ }^{10}$. In Poland, the state of the epidemic was introduced by the Regulation of the Minister of Health of 20 March $2020^{11}$. Further changes were introduced later.

The executive power decided not to introduce the state of emergency. All restrictions on the rights and freedoms of individuals, as well as economic and social rights introduced to ensure safety and health protection, were implemented by virtue of regulations and the COVID-19 special purpose act.

\section{Use of health care during the epidemic}

In a state of epidemic, which have been in Poland since 20 March 2020 , doctors' work is particularly valuable and scarce. Both the doctors employed on a contract of employment and based on civillaw agreements can count on various forms of legal protection of their work, but also their economic rights related to working conditions have been limited.

9 A. Surówka, Ochrona zdrowia w systemie praw i wolności, „Jurysta” 2005, z. 8. s. 7-13. 20 J. Trzciński, Komentarz do art. 68 Konstytucji, [w:] L. Garlicki (red.), Konstytucja Rzeczypospolitej Polskiej. Komentarz, t. III, Warszawa 2003, s. 3-4.

10 Journal of Laws of 2020, item 374.

11 Journal of Laws of 2020, item 491. 
Pursuant to the Regulation of the Minister of Health of 24 March $2020^{12}$, the ban on movement did not apply to satisfying necessary needs of everyday life, including health care or psychological care for an individual or its relatives.

The legislator did not prohibit the citizens to use health care, thus the right to health was preserved. It should be noted that this right has undergone significant modifications, the evolution of the way we exercise the right to health is associated with the evolution of the provision of public services, including health services, as well as the operations of public administration itself.

First of all, preventive examinations and some treatments not aimed at saving lives have been limited. Public authorities have encouraged citizens to postpone health checks and treatments not aimed at saving lives. The possibility of admitting patients with dental diseases was also limited, except for selected institutions designated to provide anti-infection treatment.

The communiqués of the Chief Sanitary Inspector in Poland show that patients should be widely informed about the necessity of contacting by phone in order to determine the possibility of a visit at the clinic and in order to have an initial interview with a patient. Great emphasis has been put on the use of electronic forms such as telemedicine services. Until a few months ago, doctors were quite skeptical about such solutions, and in the era of pandemic they proved to be necessary.

Moreover, an e-prescription is an extremely useful tool - especially nowadays (article 95b clause 1 of the Act of 6 September 2001 - Pharmaceutical Law (Journal of Laws No. 126, item 1381)).

12 ORDINANCE MINISTER OF HEALTH of March 24, 2020 amending the regulation on the declaration of an epidemic in the territory of the Republic of Poland (Journal of Law of 2020, item 522). 
This is one of positive effects of pandemic - medical entities have learnt about technological possibilities they currently have.

\section{Employees of medical entities - rights granted and restrictions imposed}

The Act of 5 December 2008 on preventing and combating human infections and infectious diseases ${ }^{13}$, hereinafter referred to as "special purpose act" or "special purpose act on combating infections", introduced the obligation to perform work by health care employees, which on the one hand, aims at better access to health care for coronavirus-infected patients, while on the other hand it is a manifestation of the limitation of economic rights to working conditions.

The changes for medical entities related to the introduction of the epidemic concern making available to the voivode the real estate, premises and areas provided for in the anti-epidemic plans. An important change for medical entities, and in particular for their employees and other persons performing medical professions, is the possibility of public administration bodies to refer to work on combating the epidemic in connection with SARS-CoV-2 infections. It should be also noted that it is possible to refer other persons to work on combating the epidemic provided that the referral is justified by current needs of public administration bodies managing the epidemic.

In accordance with article 47 clause 1 of the special purpose act, employees of medical entities, persons performing medical professions and persons with whom contracts for

\footnotetext{
13 Journal of Laws of 2019, item 1239, as amended.
} 
health services have been signed can be referred to work on combating the epidemic.

Other persons can be also referred to work on combating the epidemic if their referral is justified by the current needs of the entities directing the fight against the epidemic. The legislator has also provided for some exclusions, which include age, health conditions, as well as having children and bringing up children, among others.

In practice, this means that every health care worker, regardless of the form of employment, can be obliged to work in the event of COVID -19 threat. This applies both to doctors working in the public system on the basis of an employment contract, civil-law contract, and those who work outside and run their own medical practice.

It should be noted that there are opinions in the legal information systems, however, of different quality, indicating that referring physicians of other specializations to infectious disease wards will only be possible if the parties define this possibility in the contract, which constitutes some misinterpretation. This can refer to the delegation of an employee by an employer analogously to art. 42 of the Labour Code ${ }^{14}$, which stipulates the delegation of an employee, and not to the regulations of art. 47 clause 1 of the special purpose act on combating infections. This mode is completely independent of the content of the civil law contract, it is entirely of public character and is secured by administrative sanction from PLN 5,000 to PLN 30,000, imposed many times on a bookings basis, in case of failure to meet the obligation.

Pursuant to art. 47 clauses 2 and 4 of the special purpose act on combating infections, a decision on referral to work on combating the epidemic in the territory of the province where the

14 Journal of Laws 2020, item 1320, uniform text. 
person being referred has a place of residence or is employed is issued by a competent voivode, and in the case of referral to work in the territory of another province - by the minister in charge of health. This is an administrative-legal mode because of lack of freedom in establishing this relationship; it is imposed unilaterally, which is typical of administrative-legal relations. Therefore, as a consequence, there is no equivalence of the parties to this relationship. By way of an administrative decision being immediately enforceable, the voivode or the Minister of Health defines in detail the provisions of the act. It is necessary to distinguish between the regulation under article 47 of the special purpose act on combating infections and the situation of the doctor's delegation to work on the basis of the delegation under the Labour Code. The employment relationship of a health care employee is subject to protection, as the current employer is obliged to grant unpaid leave for a specified period of time by way of a decision, and the period of unpaid leave is included in the period of work which influences the employee's entitlements at that employer.

The medical entity to which a person has been referred to work on combating the epidemic establishes with that person an employment relationship for the time of performing specific work, for a period not longer than that specified in the decision. Moreover, such person is entitled to a base salary not lower than 150 per cent of the average base salary provided for on a given position at the medical entity indicated in the decision on a referral to work on combating the epidemic. With regard to the remuneration of a person referred to work, it should be noted that the remuneration cannot be lower than that which the person referred to work on combating the epidemic received in a month preceding a month of referral to work. A person referred to work on 
combating the epidemic is also entitled to reimbursement of travel, accommodation and food costs, unless these have been provided by the employer at the place of work ${ }^{15}$.

The manner of proceedings of the Voivode or the Minister of Health issuing a work order in a form of an administrative decision is also simplified and digitalized. Pursuant to clause $6 \mathrm{a}$ of article 47 of the special purpose act on combating infections, the decisions in question:

1) can be communicated in any possible way ensuring that the decision reaches the addressee, including orally;

2) do not require justification;

3) are communicated in a manner other than in writing, and are subsequently delivered in writing once the reasons preventing service in this manner cease to exist.

The legislator has also decided to introduce restrictions related to the provision of work by health care employees in several medical facilities.

On 29 April 2020, the Regulation of the Minister of Health of 28 April 2020 on standards regarding restrictions when providing health care services to patients other than SARS-CoV-2 infected patients and those suspected of such infection by health professionals having direct contact with SARS-CoV-2 infected patients and those suspected of such infection ${ }^{16}$ entered into force.

The restriction applies to persons included in the list of positions due to the provision of health care services in connection with combating COVID - 19 .

15 A. Zoll, Problemy służby zdrowia w świetle doświadczeń RPO, „Prawo i Medycyna" 2000 , z. 8 , s. 8.

16 Journal of Laws 2020, item 775. 
Providing a person performing health profession with information about being included in the list of positions of a given medical entity constitutes a basis for discontinuation - during the period covered by the limitation - of the provision of work on the basis other than the employment relationship or of performing health profession in the form of a professional practice referred to in article 5 clause 2 of the Act of 15 April 2011 on medical activities (Journal of Laws 2011.112.654, as amended) except for medical entity providing hospital services exclusively connected with combating COVID - 19 or a separate organisational unit of a medical entity providing health care services in connection with combating COVID - 19. The guidance on the consequences of restriction should be included in the information on the entry into the list of positions issued by the head of the medical entity.

The director of a voivodeship department of the National Health Fund, at the request of the head of the medical entity, can grant consent to the provision of health care services by a person performing health profession despite being covered by a limitation in order to ensure sufficient access to medical services.

\section{Conclusion}

To sum up, it should be pointed out that at present there are no scientific data on the length of the epidemic. Undoubtedly, an efficient system well-equipped with personal protective equipment and medical personnel is a condition for exercising the right to health. However, the issue of forcing doctors by way of high financial penalties to work in specialized COVID-19 infectious disease hospitals should be considered. An efficient health care system is conditioned by the scope and number of health care services provided. Therefore, laws must be passed that will 
create opportunities for other public authorities to implement this widely understood task. It is necessary to define specific tasks by law concerning health protection and granting appropriate competences in this respect. In addition, guarantees should be given to citizens in the event of failure or inadequate fulfillment of these tasks.

Undoubtedly, the right to health as a result of changes connected with the coronavirus epidemic has evolved and become digitalized. The effectiveness of such medical services will be assessed in practice. The state should not only protect the citizens but also medical personnel so that their working conditions encourage and are conducive to the provision of assistance during the COVID-19 epidemic.

\section{References:}

BOĆ J. (red.), Konstytucje Rzeczypospolitej oraz komentarz do konstytucji RP z 1997 roku, Wrocław: „Kolonia”, 1998, s. 78. ISBN 83-9084154-1.

KARKOWSKA D., Prawa pacjenta, Warszawa: Wolters Kluwer Polska, 2009, s. 23 i n. ISBN 978-83-7601-972-7.

PIECHOTA M., Konstytucyjne prawo do ochrony zdrowia jako prawo socjalne i prawo podstawowe, Roczniki administracji i Prawa. Teoria i Praktyka. Rok XII, Sosnowiec 2012, s. 95.

SURÓWKA A., Ochrona zdrowia w systemie praw i wolności, „Jurysta” 2005, z. 8. s. 7-13. 20

TRZCIŃSKI J., Komentarz do art. 68 Konstytucji, [w:] L. Garlicki (red.), Konstytucja Rzeczypospolitej Polskiej. Komentarz, t. III, Warszawa: Wydawnictwo Sejmowe, 2003, s. 3-4. ISBN 83-7059-449-2.

ZOLL A., Problemy służby zdrowia w świetle doświadczeń RPO, „Prawo i Medycyna" 2000, z. 8, s. 8. 